\title{
PENGARUH PENERAPAN AKUNTABILITAS KEUANGAN, PEMANFAATAN TEKNOLOGI INFORMASI, KOMPETENSI APARATUR PEMERINTAH DAN KETAATAN PERATURAN PERUNDANGAN TERHADAP KINERJA INSTANSI PEMERINTAH (GOOD GOVERNANCE) PADA ORGANISASI PERANGKAT DAERAH KABUPATEN BENGKALIS
}

\author{
Dariana, Annisa Meidyaroza Harrie \\ Sekolah Tinggi Ilmu Ekonomi (STIE) Syariah Bengkalis \\ dariana@gmail.com, annisa.mdrh@gmail.com \\ https://doi.org/10.46367/jas.v4i1.224
}

Received: Mei 11, 2020 Revised: Jun 06, 2020 Accepted: Jun 18, 2020 Published: Jun 25, 2020

\begin{abstract}
This research aims to examine the effect of the application of financial accountability, utilization of information technology, the competence of government officials and compliance with laws and regulations on the performance of government agencies (good governance) partially and simultaneously in the organization of Bengkalis Regency. This research is a survey research with 160 respondents using a saturated sample method. The number of questionnaires returned was able to be processed as many as 130 respondents. This research uses multiple linear regression analysis models. The results of this research indicate that partially and simultaneously financial accountability, utilization of information technology, the competence of local government officials and obedience of laws and regulations have a significant effect on the performance of government agencies (good governance) in Bengkalis Regency regional apparatus organizations.
\end{abstract}

Keywords: Financial Accountability, Information Technology, Competence, Compliance, Good Governance.

\begin{abstract}
ABSTRAK
Penelitian ini bertujuan untuk menguji pengaruh penerapan akuntabilitas keuangan, pemanfaatan teknologi informasi, kompetensi aparatur pemerintah dan ketaatan peraturan perundangan terhadap kinerja instansi pemerintah (good governance) pada organisasi perangkat daerah Kabupaten Bengkalis secara parsial dan simultan. Penelitian ini merupakan penelitian survei dengan jumlah responden sebanyak 160 dengan menggunakan metode sampel jenuh. Jumlah kuesioner yang dikembalikan dan dapat di olah sebanyak 130 Responden. Penelitian ini menggunakan model analisis regresi linier berganda. Hasil penelitian ini menunjukkan bahwa secara parsial dan simultan akuntabilitas keuangan, pemanfaatan teknologi informasi, kompetensi aparatur pemerintah daerah dan ketaatan peraturan perundangan berpengaruh signifikan terhadap kinerja instansi pemerintah (good governance) pada organisasi perangkat daerah Kabupaten Bengkalis.
\end{abstract}

Kata kunci: Akuntabilitas Keuangan, Teknologi Informasi, Kompetensi, Ketaatan, Good Governance. 


\section{PENDAHULUAN}

Wacana tentang good gorvenance (tata Pemerintahan yang baik) merupakan isu yang paling penting mengemuka belakangan ini. Untuk mencapai good gorvenance itu sendiri, salah satu prinsip yang harus dipenuhi adalah Akuntabilitas. Sehubungan dengan hal tersebut seperangkat peraturan perundangundangan pun telah digulirkan, demikian pula Pemerintah dan seluruh elemen bangsa secara sistematis dan berkelanjutan telah mengambil berbagai kebijakan dan kegiatan yang terkait dengan tuntutan terselenggaranya Pemerintahan yang baik.

Good governance juga banyak mengandung arti, diantaranya menurut Bank Dunia (World Bank) adalah merupakan cara kekuasaan yang digunakan dalam mengelola berbagai sumber daya sosial dan ekonomi untuk pengembangan masyarakat (Mardoto 2009a). Dan menurut UNDP (United National Development Planning) memberikan definisi, praktek penerapan kewenangan pengelolaan berbagai urusan. Penyelenggaraan Negara secara politik, ekonomi dan administrative di semua tingkatan. Ada tiga pilar good governance yang penting, yaitu: kesejahteraan rakyat (economic governance), proses pengambilan keputusan (political governance) dan tata laksana pelaksanaan kebijakan (Prasetijo 2009a, 23).

Alasan memilih Kabupaten Bengkalis karena adanya kelemahan yang perlu menjadi perhatian ke depan antara lain, keterlambatan penyetoran sisa uang yang harus dipertanggungjawabkan, pencatatan atas penerimaan, pencatatan atas persediaan, pencatatan dan pengelolaan aset tetap, kelebihan pembayaran atas pelaksanaan kegiatan, serta kelemahan dalam sistem pengendalian intern pemerintah (SPIP). Disebutkannya, laporan keuangan tahun 2015, Pemerintah Kabupaten Bengkalis berhasil memperoleh WTP dari Badan Pemeriksa Keuangan Republik Indonesia. Perolehan opini tersebut justru menjadi tantangan untuk memperbaiki beberapa kelemahan dalam pengelolaan keuangan, pengelolaan aset, serta pelaksanaan program dan kegiatan.

Beberapa fenomena umum dalam penggunaan sistem informasi yang dirasakan oleh pegawai di instansi Pemerintah Kabupaten Bengkalis sebagai pengguna sistem informasi dalam melakukan dan menyelesaikan pekerjaannya dia antaranya yaitu: (1) masih adanya gangguan koneksi dalam sistem informasi itu sendiri yang menyebabkan sistem menjadi tidak cepat dalam pemrosesan data, (2) pengguna memerlukan pelatihan sistem informasi yang ada jika terjadi kerusakan, (3) pengguna merasa output yang dihasilkan dari sistem informasi yang ada belum sesuai dengan keinginan pengguna, dan (4) pengguna sistem informasi yang ada dapat diperbaiki kualitasnya sehingga akhirnya dapat menunjang kinerja dari pegawai sebagai pengguna sistem informasi.

Selain menindak lanjuti temuan-temuan tersebut sekda juga menghimbau Organisasi Perangkat Daerah meningkatkan kualitas kerja serta menyampaikan laporan keuangan tepat waktu. Terlambatnya penyampaian laporan keuangan Organisasi Perangkat Daerah tersebut menyebabkan terlambatnya penyampaian laporan keuangan oleh Pemerintah Bengkalis kepada BPK. Keterlambatan tersebut terjadi karena masalah teknis karena ada sejumlah Organisasi Perangkat Daerah yang belum selesai menyusun Rencana Kerja Anggarannya (RKA) (AntaraNews 2016). 
Sehubungan dengan hal tersebut seperangkat peraturan perundangundangan telah digulirkan. Salah satunya adalah Peraturan Presiden Republik Indonesia No. 29 Tahun 2014 tentang Sistem Akuntabilitas Kinerja Instansi Pemerintah pengganti dari Instruksi Presiden No.7 Tahun 1999 tanggal 15 Juni 1999, ini merupakan salah satu upaya Pemerintah dalam Mewujudkan praktek good governance khususnya Akuntabilitas untuk meningkatkan pelaksanaan pemerintahan yang lebih berdaya guna, berhasil guna, bersih dan bertanggungjawab.

Dalam mewujudkan praktik Akuntabilitas tersebut, setiap Organisasi Perangkat Daerah diwajibkan menyerahkan Surat Pertanggungjawaban (SPj) kepada pemerintahan daerah yang kemudian harus menyerahkan Laporan Pertanggungjawaban ( $\mathrm{LPj}$ ) atas kinerjanya secara horizontal kepada DPRD dan pihak terkait dan akuntabilitas secara vertikal dengan menyerahkan Laporan Akuntabilitas Kinerja Instansi Pemerintah (LAKIP) kepada pemerintah secara berjenjang. Sesuai dengan undang-undang Nomor 23 Tahun 2004, dimana yang telah digantikan dengan Undang- Undang No. 9 Tahun 2015 yaitu Kepala Daerah disamping menyampaikan akuntabilitas keuangan, juga menyampaikan laporan akuntabilitas kinerja dalam ukuran efisiensi dan efektivitas serta melaksanakan tugas lain sesuai dengan ketentuan peraturan perundang-undangan.

Kinerja Instansi Pemerintah setiap daerah berbeda-beda. Beberapa faktor yang mempengaruhi perbedaan tersebut adalah akuntabilitas keuangan, pemanfaatan teknologi informasi, kompetensi aparatur pemerintah dan ketaatan peraturan perundangan.

Penerapan akuntabilitas tentunya akan mempengaruhi kinerja instansi pemerintah. Dalam rangka menciptakan pemerintahan yang baik dan akuntabel dibutuhkan salah satu indikasi yang sangat perlu diperhatikan yaitu pengembangan penerapan sistem akuntabilitas yang tepat, jelas dan nyata. Di dalam dimensi akuntabilitas publik, laporan hasil kinerja diwujudkan melalui ukuran-ukuran kuantitatif. Adapun akuntabilitas keuangan (financial accountability), dimana akuntabilitas keuangan suatu instansi pelayanan publik akan dimintai pertanggungjawaban seberapa besar efektifitas dan efisiensi penyelenggaraan setiap kegiatan publik yang notabene dibiayai oleh uang rakyat.

Hal kedua yang dapat mempengaruhi kinerja instansi pemerintah daerah adalah pemanfaatan teknologi informasi (e-government). Kewajiban pemanfaatan teknologi informasi oleh pemerintah dan pemerintah daerah diatur dalam Peraturan Pemerintah Nomor 65 Tahun 2010 tentang Sistem Informasi Keuangan Daerah yang merupakan pengganti dari Peraturan Pemerintah Nomor 56 Tahun 2005.

Teknologi informasi sudah menjadi pilihan utama dalam menciptakan sistem informasi suatu organisasi yang tangguh dan mampu melahirkan keunggulan kompetitif ditengah persaingan yang semakin ketat saat ini. Investasi di bidang teknologi informasi dalam suatu organisasi umumnya dimaksudkan untuk memberikan kontribusi terhadap kinerja individual anggota organisasi dan institusi.

Teknologi informasi juga memiliki pengertian yaitu suatu teknologi yang digunakan untuk mengelola data. Pengolahan itu termasuk memproses, mendapatkan, menyusun, menyimpan, memanipulasi data dalam berbagai cara 
untuk menghasilkan informasi yang berkualitas, yaitu informasi yang relevan, akurat dan tepat waktu (Hamzah dan Nina 2011, 57).

Selain itu, teknologi informasi yang saat ini kita ketahui banyak manfaat yang ditawarkan oleh suatu teknologi informasi antara lain kecepatan pemrosesan transaksi dan penyiapan laporan, keakuratan perhitungan, penyimpanan data dalam jumlah besar, biaya pemrosesan yang lebih rendah, kemampuan multiprocessing.

Dikaitkan dengan kompetensi, kompetensi adalah menunjukkan karakteristik yang mendasari perilaku yang menggambarkan motif, karakteristik pribadi, konsep diri, nilai-nilai, pengetahuan atau keahlian yang dibawa seseorang yang bekinerja unggul di tempat kerja (Palan 2007, 84). Standar kompetensi adalah spesifiksi atau sesuatu yang dibakukan, memuat persyaratan minimal yang harus dimiliki seseorang yang akan melakukan pekerjaan tertentu agar orang yang bersangkutan mempunyai kemampuan melaksanakan pekerjaan dengan hasil baik.

Ketaatan pada peraturan perundangan pun menjadi pertimbangan atas keberhasilan kinerja Instansi Pemerintah. Di Indonesia, Peraturan-peraturan perundangan tentang Keuangan Negara diatur dalam UUD 1945, Undang-undang (UU), keputusan Presiden (Keppres) dan peraturan pelaksanaan lainnya. Akuntabilitas tidak berjalan efektif tanpa adanya transparansi dan aturan hukum yang jelas, sehingga pengembangan akuntabilitas dibutuhkan suatu mekanisme dan peraturan yang jelas (Sipka 2017, 1).

Penelitian ini sebelumnya sudah pernah diteliti oleh Ardianto (2010) yang membedakan penelitian ini dengan penelitian sebelumnya adalah terletak pada objek penelitian, yaitu penelitian sebelumnya di Organisasi Perangkat Daerah Kabupaten Kuantan Singingi sedangkan pada penelitian ini yang akan saya lakukan pada Organisasi Perangkat Daerah Kabupaten Bengkalis. Alasan memindahkan objek penelitian adalah terdapatnya perbedaan kinerja antara objek yang diambil oleh Ardianto.

Dilihat dari hasil temuan-temuan diatas dapat disimpulkan bahwa kinerja Pemerintah Daerah Kabupaten Bengkalis belum sepenuhnya maksimal untuk mewujudkan pemerintahan yang Good Governance.Yang mana laporan keungan yang dihasilkan belum memenuhi kriteria nilai informasi yaitu keandalan dan ketepatan waktu,mengingat keandalan ketepatan waktu merupakan unsur penting dalam Laporan Keuangan Perangkat Daerah (LKPD) sebagai dasar pengambilan keputusan.

\section{TELAAH LITERATUR}

\section{Akuntabilitas Keuangan}

Menurut Mahmudi Akuntabilitas adalah kewajiban agent (Pemerintah) untuk mengelola sumber daya, melaporkan, dan mengungkapkan segala aktivitas dan kegiatan yang berkaitan dengan penggunaan sumber daya publik kepada pemberi mandat (principal) (Mahmudi 2010, 23). Akuntabilitas mensyaratkan bahwa pengambil keputusan berprilaku sesuai dengan mandat yang diterimanya. Untuk itu, perumusan kebijakan bersama-sama dengan cara dan hasil kebijakan tersebut harus dapat diakses dan dikomunikasikan secara vertikal maupun horizontal dengan baik (Sulistyaningrum 2005, 193). 
Lain halnya menurut Lawton dan Rose, Akuntabilitas dapat dikatakan sebagai sebuah proses dimana seseorang atau sekelompok orang yang diperlukan untuk membuat laporan aktivitas mereka dan dengan cara yang mereka sudah atau belum ketahui untuk melaksanakan pekerjaan mereka. Akuntabilitas sebagai salah satu prasyarat dari penyelenggaraan Negara yang baru, didasarkan pada konsep organisasi dalam manajemen yang menyangkut: (1) Luas kewenangan dan rentang kendali (spand of control) organisasi. (2) Faktor-faktor yang dapat dikendalikan (controllable) pada level manajemen atau tingkat kekuasaan tertentu (Nico 2007, 24).

Rasul (2003, 254) menjelaskan bahwa terdapat empat dimensi akuntabilitas yang harus dipenuhi oleh organisasi sektor publik, yaitu: (1) Akuntabilitas kejujuran dan akuntabilitas hukum (accountability for probity and legality). Akuntabilitas kejujuran terkait dengan penghindaran penyalahgunaan jabatan, sedangkan akuntabilitas hukum terkait dengan jaminan adanya kepatuhan terhadap hukum dan peraturan lain yang diisyaratkan dalam penggunaan sumber dana publik. (2) Akuntabilitas proses (process accountability). Akuntabilitas proses terkait dengan apakah prosedur yang digunakan dalam melaksanakan tugas sudah cukup baik dalam hal kecukupan sistem informasi akuntansi, sistem informasi manajemen, dan prosedur administrasi. (3) Akuntabilitas program (program accountability). Akuntabilitas program terkait dengan pertimbangan apakah tujuan yang ditetetapkan dapat dicapai atau tidak. (4) Akuntabilitas kebijakan (policy accountability). Akuntabilitas kebijakan terkait dengan pertanggungjawaban pemerintah, baik pusat maupun daerah, atas kebijakankebijakan yang diambil pemerintah terhadap DPR/DPRD dan masyarakat luas.

Akuntabilitas keuangan menurut Abdul Halim merupakan pertanggungjawaban mengenai integritas keuangan, pengungkapan, dan ketaatan terhadap peraturan perundangan. Sasaran pertanggungjawaban ini adalah laporan keuangan yang disajikan dan peraturan perundangan yang berlaku yang mencangkup penerimaan, penyimpanan, dan pengeluaran uang oleh instansi pemerintah (Halim 2008, 254). Hal ini sejalan yang dikemukan oleh Premchand bahwa: The main instruments of financial accountability are government budgets, periodically published data on public finances, annual accounts, and the investigative and other general reports prepared by independent agencies.

\section{Teknologi Informasi}

E-government mengacu pada penggunaan teknologi informasi oleh pemerintahan,seperti menggunakan internet, yang mempunyai kemampuan menghubungkan keperluan penduduk, bisnis, dan kegiatan lainnya. Bisa merupakan suatu proses transaksi bisnis antara publik dengan pemerintah melalui sistem otomasi dan jaringan internet, lebih umum lagi dikenal sebagai world wide web. Pada intinya e-government adalah penggunaan teknologi informasi yang dapat meningkatkan hubungan antara pemerintah dan pihak-pihak lain. penggunaan teknologi informasi ini kemudian menghasilkan hubungan bentuk baru seperti: G2C (Governmet to Citizen), G2B (Government to Business), dan G2G (Government to Government) (Kamang 2009, 6).

Karena perkembangan teknologi semakin pesat sehingga kebutuhan manusia akan teknologi juga semakin banyak. Salah satu saat ini yang memanfaatkan teknologi informasi adalah perusahaan/organisasi. Penggunaan 
teknologi informasi dalam sebuah organisasi sangatlah penting, untuk Apakah dengan informasi teknologi mampu meningkatkan efisiensi sebuah perusahaan/organisasi, sehingga dalam penerapan informasi teknologi dibutuhkan orang yang handal yang dapat berjalan dengan baik. Sistem teknologi informasi memberikan peran utama di dalam organisasi, yaitu untuk meningkatkan efisiensi, efektivitas, komunikasi, kolaborasi, dan kompetitif (Jogiyanto 2005, 18).

\section{Kompetensi Aparatur Pemerintah}

Wibowo (2008, 34) menyatakan Kompetensi adalah suatu kemampuan untuk melaksanakan atau melakukan suatu pekerjaan atau tugas yang dilandasi atas keterampilan dan pengetahuan serta dukungan oleh sikap kerja yang dituntut oleh pekerjaan tersebut. Kompetensi menurut UU No 13 Tahun 2003 pasal 1 (10) tentang Ketenagakerjaan adalah kemampuan kerja setiap individu yang mencakup aspek pengetahuan, keterampilan dan sikap kerja yang sesuai dengan standar yang ditetapkan (RI 2003).

Kompetensi menurut Ebta (2005) adalah kewenangan (kekuasaan) untuk menentukan (memutuskan sesuatu); kemampuan menguasai gramatika suatu bahasa secara abstrak atau batiniah. Moeheriono $(2009,4)$ mengungkapkan bahwa kompetensi merupakan sebuah karakteristik dasar seseorang yang mengindikasikan cara berpikir, bersikap, dan bertindak serta menarik kesimpulan yang dapat dilakukan dan dipertahankan oleh seseorang pada waktu periode tertentu.

Kompetensi sebagaimana dimaksud Pasal 69 UU no 5 tahun 2014 ayat (1) meliputi: (1) Kompetensi teknis yang diukur dari tingkat dan spesialisasi pendidikan, pelatihan teknis fungsional, dan pengalaman bekerja secara teknis; (2) Kompetensi manajerial yang diukur dari tingkat pendidikan, pelatihan struktural atau manajemen, dan pengalaman kepemimpinan; dan (3) Kompetensi sosial kultural yang diukur dari pengalaman kerja berkaitan dengan masyarakat majemuk dalam hal agama, suku, dan budaya sehingga memiliki wawasan kebangsaan (RI 2014).

Hutapea dan Thoha $(2008,8)$ mengungkapkan bahwa ada tiga komponen utama pembentukan kompetensi, yaitu: (1) Pengetahuan (knowledge) adalah informasi yang dimiliki seorang pegawai untuk melaksanakan tugas dan tanggungjawabnya sesuai bidang yang digelutinya. (2) Keterampilan (Skill) merupakan suatu upaya untuk melaksanakan tugas dan tanggung jawab yang diberikan perusahaan kepada seorang pegawai dengan baik dan maksimal. (3) Sikap (attitude) merupakan pola tingkah seseorang pegawai dalam melaksanakan tugas dan tanggungjawabnya sesuai dengan peraturan perusahaan/pemerintahan.

Secara spesifikasi kualifikasi Pegawai Negeri Sipil (PNS) dapat ditinjau dari tiga unsur, unsur utama yaitu: (1) Keahlian, PNS antara lain harus memiliki pengalaman yang sesuai dengan tugas dan fungsinya, memiliki pengetahuan yang sesuai dengan tugas dan fungsinya, memiliki wawasan yang luas dan beretika. (2) Kemampuan Teknis, PNS antara lain harus memahami tugas-tugas dibidangnya. (3) Sifat-sifat personal yang baik, PNS harus memiliki didiplin yang tinggi, jujur, menaruh minat, terbuka,objektif, pandai berkomunikasi, selalu siap dan terlatih (Prayitno dan Suprapto 2002).

Kompetensi profesi adalah kemampuan untuk menguasai keterampilan/ keahlian pada bidang tertentu, sehingga tenaga kerja mampu bekerja dengan cepat 
tepat, teratur, dan bertanggungjawab. Kompetensi individu adalah kemampuan yang diarahkan pada keunggulan tenaga kerja, baik penguasaan ilmu pengetahuan dan teknologi (iptek) maupun kemampuan daya saing. Dan kompetensi sosial adalah kemampuan yang diarahkan pada kemampuan tenaga kerja dalam menyesuaikan diri dengan lingkungan, sehingga mampu mengaktualisasikan dirinya dilingkungan masyarakat maupun lingkungan kerjanya (Muins 2000, 40).

Aparatur menurut Ebta (2005) bahwa aparatur adalah perangkat, alat (negara, pemerintah); para pegawai (negeri); negara alat kelengkapan Negara terutama meliputi bidang kelembagaan, ketatalaksanaan, dan kepegawaian, yang mempunyai tanggung jawab melaksanakan roda pemerintahan sehari-hari; pemerintah pegawai negeri; alat negara; aparatur negara. Undang-Undang Nomor 23 Tahun 2014 tentang Pemerintahan Daerah menjelaskan pengertian perangkat daerah adalah unsur pembantu kepala daerah dan DPRD dalam penyelengaraan Urusan Pemerintah yang menjadi kewenangan Daerah (RI 2014).

\section{Ketaatan Peraturan Perundangan}

Di Indonesia, peraturan-peraturan perundangan tentang keuangan Negara diatur dalam UUD 1945, Pasal 23 ayat 5 dan undang-undang APBN, pemerintah diharuskan membuat pertanggungjawaban keuangan Negara tersebut, merupakan bagian dari akuntabilitas publik yang harus disampaikan oleh pemerintah atas penggunaan keuangan Negara yang diperoleh dari uang rakyat dan untuk tujuan kesejahteraan rakyat.

Attamimi memberikan batasan peraturan perundangan adalah peraturan negara, yang ditingkat pusat maupun tingkat daerah yang dibentuk berdasarkan kewenangan perundangan, baik bersifat atribusi maupun bersifat delegasi. Attamimi juga memberikan batasan mengenai peraturan perundang-undangan sebagai berikut : Semua aturan hukum yang dibentuk oleh semua tingkat lembaga dalam bentuk tertentu, dengan prosedur tertentu, biasanya disertai sanksi dan berlaku umum serta mengikat rakyat. Oleh sebab itu, warga Negara Republik Indonesia mentaati semua peraturan perundangan yang berlaku.

Rasul (2003, 11) mengembangkan teori Hans Kelsen, dalam teorinya mengenai jenjang hukum (Stuffen theories), mengemukakan bahwa norma-norma hukum itu berjenjang dan berlapis-lapis dalam suatu tata susunan, dimana norma yang paling rendah bersumber dan berdasarkan pada norma yang lebih tinggi lagi, sehingga sampai dengan suatu norma yang paling tinggi yaitu norma dasar (grundnorm).

\section{Kinerja Instansi Pemerintah (Good Governance)}

Semakin meningkatnya tuntutan masyarakat terhadap penyelenggaraan pemerintah yang baik dan bersih (good governance dan clean government) telah mendorong pengembangan dan penerapan sistem pertanggungjawaban yang jelas, tepat, teratur dan efektif yang dikenal dengan Sistem Akuntabilitas Kinerja Instansi Pemerintah (SAKIP). Penerapan sistem tersebut bertujuan agar penyelenggaraan pemerintahan dan pembangunan dapat berlangsung secara berdaya guna, berhasil guna, bertanggungjawab dan bebas dari praktik kolusi, korupsi dan nepotisme (KKN).

Berdasarkan Pedoman Penyusunan Pelaporan Akuntabilitas Kinerja Instansi Pemerintah yang ditetapkan oleh Kepala Lembaga Administrasi Negara, 
pelaksanaan AKIP harus berdasarkan antara lain pada prinsip-prinsip sebagai berikut: (1) Adanya komitmen dari pimpinan dan seluruh staf instansi yang bersangkutan. (2) Berdasarkan suatu sistem yang dapat menjamin penggunaan sumber sumber daya secara konsisten dengan peraturan perundang-undangan yang berlaku. (3) Menunjukkan tingkat pencapaian sasaran dan tujuan telah ditetapkan Akuntabilitas Instansi Pemerintah Pusdiklatwa BPKP-2007. (4) Berorientasi pada pencapaian visi dan misi, serta hasil dan manfaat yang diperoleh. (5) Jujur, objektif, transparan, dan akurat. (6) Menyajikan keberhasilan/kegagalan dalam pencapaian sasaran dan tujuan yang telah ditetapkan (Sumiati 2010).

Selain prinsip-prinsip tersebut diatas, agar pelaksanaan sistem akuntabilitas kinerja instansi pemerintah lebih efektif, sangat diperlukan komitmen yang kuat dari organisasi yang mempunyai wewenang dan bertanggungjawab dibidang pengawasan dan penilaian terhadap akuntabilitas kinerja instansi pemerintah.

\section{METODE PENELITIAN}

Penelitian ini dilaksanakan pada Pemerintah Daerah Kabupaten Bengkalis yang terdapat 32 Organisasi Perangkat Daerah yang menjadi tempat penelitian yang terdiri dari: 2 Sekretariat, 1 Inspektorat, 7 Badan, 21 Dinas dan 1 Kantor pada tahun 2018. Jumlah populasi dalam penelitian ini berjumlah 160 responden. Adapun jumlah sampel yang digunakan dalam penelitian ini adalah dengan menggunakan metode sensus atau sampel jenuh. Teknik pengumpulan data yang digunakan yaitu: kuesioner, wawancara, dokumentasi dan studi pustaka. Teknik analisis data dalam penelitian ini diuji dengan menggunakan uji statistik.

\section{HASIL DAN PEMBAHASAN PENELITIAN}

\section{Deskripsi Responden}

$\underline{\text { Tabel } 1 \text { Jumlah Sampel Dan Tingkat Pengembalian Kuesioner }}$

\begin{tabular}{lcc}
\hline \multicolumn{1}{c}{ Keterangan } & Jumlah & Persentase \% \\
\hline Kuesioner yang disebar & 160 & $100 \%$ \\
Kuesioner yang kembali & 130 & $81,25 \%$ \\
Kuesioner yang tidak kembali & 30 & $18,75 \%$ \\
Kuesioner yang tidak dapat diolah & 0 & $0 \%$ \\
Kuesioner yang dapat diolah & 130 & $81,25 \%$ \\
\hline Sumber: Data Olahan & &
\end{tabular}

Tabel 2 Responden Berdasarkan Jenis Kelamin

\begin{tabular}{lcc}
\multicolumn{1}{c}{ Jenis Kelamin } & $\begin{array}{c}\text { Jumlah } \\
\text { (Orang) }\end{array}$ & $\begin{array}{c}\text { Presentase } \\
(\mathbf{\%})\end{array}$ \\
\hline Laki-Laki & 40 & $30,77 \%$ \\
Perempuan & 90 & $69,23 \%$ \\
\hline \multicolumn{1}{c}{ Total } & $\mathbf{1 3 0}$ & $\mathbf{1 0 0 \%}$ \\
\hline Sumber: Data Olahan & &
\end{tabular}




\section{Uji Validitas}

Tabel 3 Uji Validitas

\begin{tabular}{|c|c|c|c|c|}
\hline Variabel & $\begin{array}{c}\text { Butir } \\
\text { Pertanyaan }\end{array}$ & $\mathbf{r}_{\text {hitung }}$ & $\mathbf{r}_{\text {table }}$ & Keterangan \\
\hline \multirow{5}{*}{$\begin{array}{c}\text { Penerapan } \\
\text { Akuntanbilitas } \\
\text { Keuangan } \\
\text { (X1) }\end{array}$} & PAK 1 & 0,911 & 0,171 & Valid \\
\hline & PAK 2 & 0,935 & 0,171 & Valid \\
\hline & PAK 3 & 0,895 & 0,171 & Valid \\
\hline & PAK 4 & 0,944 & 0,171 & Valid \\
\hline & PAK 5 & 0,948 & 0,171 & Valid \\
\hline \multirow{15}{*}{$\begin{array}{l}\text { Pemanfaatan } \\
\text { Teknologi } \\
\text { Informasi } \\
\text { (X2) }\end{array}$} & PTI 1 & 0,529 & 0,171 & Valid \\
\hline & PTI 2 & 0,479 & 0,171 & Valid \\
\hline & PTI 3 & 0,578 & 0,171 & Valid \\
\hline & PTI 4 & 0,739 & 0,171 & Valid \\
\hline & PTI 5 & 0,560 & 0,171 & Valid \\
\hline & PTI 6 & 0,884 & 0,171 & Valid \\
\hline & PTI 7 & 0,590 & 0,171 & Valid \\
\hline & PTI 8 & 0,811 & 0,171 & Valid \\
\hline & PTI 9 & 0,730 & 0,171 & Valid \\
\hline & PTI 10 & 0,473 & 0,171 & Valid \\
\hline & PTI 11 & 0,770 & 0,171 & Valid \\
\hline & PTI 12 & 0,755 & 0,171 & Valid \\
\hline & PTI 13 & 0,781 & 0,171 & Valid \\
\hline & PTI 14 & 0,781 & 0,171 & Valid \\
\hline & PTI 15 & 0,765 & 0,171 & Valid \\
\hline \multirow{10}{*}{$\begin{array}{l}\text { Kompetensi } \\
\text { Aparatur } \\
\text { Pemerintah } \\
\text { (X3) }\end{array}$} & KAP 1 & 0,816 & 0,171 & Valid \\
\hline & KAP 2 & 0,816 & 0,171 & Valid \\
\hline & KAP 3 & 0,823 & 0,171 & Valid \\
\hline & KAP 4 & 0,884 & 0,171 & Valid \\
\hline & KAP 5 & 0,916 & 0,171 & Valid \\
\hline & KAP 6 & 0,914 & 0,171 & Valid \\
\hline & KAP 7 & 0,874 & 0,171 & Valid \\
\hline & KAP 8 & 0,880 & 0,171 & Valid \\
\hline & KAP 9 & 0,835 & 0,171 & Valid \\
\hline & KAP 10 & 0,651 & 0,171 & Valid \\
\hline \multirow{5}{*}{$\begin{array}{c}\text { Ketaatan } \\
\text { Peraturan } \\
\text { Perundangan } \\
\text { (X4) }\end{array}$} & KPP 1 & 0,824 & 0,171 & Valid \\
\hline & KPP 2 & 0,864 & 0,171 & Valid \\
\hline & KPP 3 & 0,909 & 0,171 & Valid \\
\hline & KPP 4 & 0,878 & 0,171 & Valid \\
\hline & KPP 5 & 0,918 & 0,171 & Valid \\
\hline Kinerja & KIP 1 & 0,779 & 0,171 & Valid \\
\hline Instansi & KIP 2 & 0,776 & 0,171 & Valid \\
\hline Pemerintah & KIP 3 & 0,846 & 0,171 & Valid \\
\hline
\end{tabular}




\begin{tabular}{ccccc} 
(Y) & KIP 4 & 0,839 & 0,171 & Valid \\
& KIP 5 & 0,880 & 0,171 & Valid \\
& KIP 6 & 0,909 & 0,171 & Valid \\
& KIP 7 & 0,763 & 0,171 & Valid \\
\hline
\end{tabular}

Sumber: Data Olahan

\section{Uji Reliabilitas}

Tabel 4 Reliabilitas

\begin{tabular}{cccc}
\hline Variabel & $\begin{array}{c}\text { Cronbach's } \\
\boldsymbol{A l f a} \boldsymbol{a}\end{array}$ & Kriteria & Keterangan \\
\hline X1 & 0,959 & 0,60 & Reliable \\
X2 & 0,919 & 0,60 & Reliable \\
X3 & 0,954 & 0,60 & Reliable \\
X4 & 0,926 & 0,60 & Reliable \\
Y & 0,921 & 0,60 & Reliable \\
\hline
\end{tabular}

\section{Uji Normalitas}

Tabel 5 One-Sample Kolmogorov-Smirnov Test

\begin{tabular}{|c|c|}
\hline & $\begin{array}{c}\text { Unstandardized } \\
\text { Residual }\end{array}$ \\
\hline $\bar{N}$ & 130 \\
\hline \multirow[t]{2}{*}{ Normal Parameters ${ }^{a, b}$} &, 0000000 \\
\hline & 2,78513595 \\
\hline Most Extreme Differences Absolute &, 070 \\
\hline Positive &, 066 \\
\hline Negative &,- 070 \\
\hline Test Statistic &, 070 \\
\hline Asymp. Sig. (2-tailed) & $197^{\mathrm{c}}$ \\
\hline $\begin{array}{l}\text { a. Test distribution is Normal. } \\
\text { b. Calculated from data. } \\
\text { c. Lilliefors Significance Correction. } \\
\text { Sumber: Output SPSS }\end{array}$ & \\
\hline
\end{tabular}

Pada tabel 5 di atas terlihat bahwa hasil uji normalitas menunjukkan level signifikansi lebih besar dari $\alpha(\alpha=0,05)$ yaitu nilai Asymp. Sig. sebesar 0,197 > 0,05 yang berarti bahwa data terdistribusi dengan normal. Untuk lebih memperjelas sebaran data dalam penelitian ini maka akan disajikan dalam grafik Normal P-Plot pada gambar 1 di bawah. Dimana dasar pengambilan keputusan menurut ahli yaitu jika titik menyebar disekitar garis dan mengikuti garis diagonal, maka residual pada model regresi tersebut terdistribusi secara normal. 


\section{Gambar 1 Normal P-Plot}

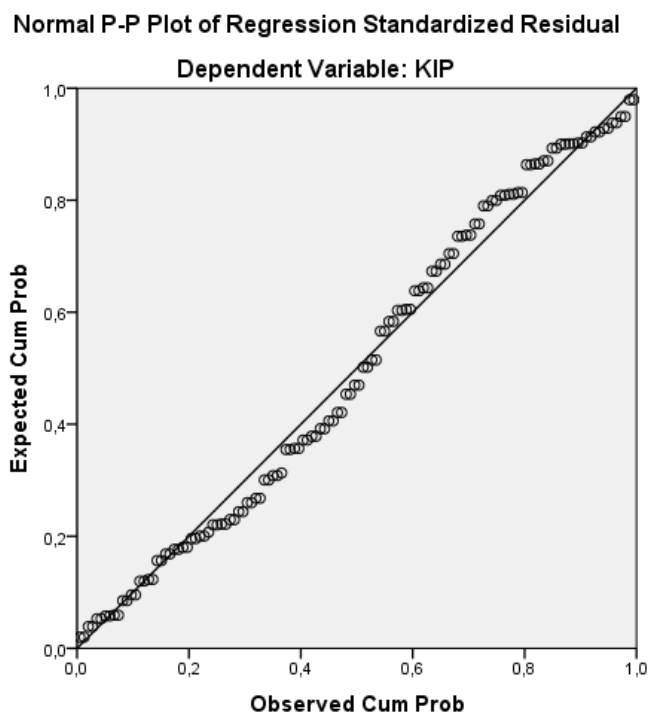

Sumber: Output SPSS

\section{Uji Regresi Linear Berganda}

\begin{tabular}{|c|c|c|c|c|c|c|}
\hline \multicolumn{7}{|c|}{ Tabel 6 Coefficients ${ }^{a}$} \\
\hline & \multirow{2}{*}{ Model } & \multicolumn{2}{|c|}{$\begin{array}{c}\text { Unstandardized } \\
\text { Coefficients }\end{array}$} & \multirow{2}{*}{$\begin{array}{c}\text { Standardized } \\
\text { Coefficients } \\
\text { Beta }\end{array}$} & \multirow{2}{*}{$t$} & \multirow{2}{*}{ Sig. } \\
\hline & & $\boldsymbol{B}$ & $\begin{array}{c}\text { Std. } \\
\text { Error }\end{array}$ & & & \\
\hline \multirow[t]{5}{*}{1} & (Constant) & 17,215 & 3,194 & & $-5,389$ & ,000 \\
\hline & $\mathrm{PAK}$ &, 465 &, 058 & ,400 & 8,084 & ,000 \\
\hline & PTI & ,357 &, 040 & ,443 & 8,852 & ,000 \\
\hline & KAP &, 112 & ,042 & ,133 & 2,687 & ,008 \\
\hline & KPP &, 523 &, 063 & ,424 & 8,263 &, 000 \\
\hline
\end{tabular}

a. Dependent Variable: KIP

Sumber: Output SPSS

Berdasarkan tabel 6 di atas, persamaan regresi yang dihasilkan adalah: $\mathrm{KIP}=17,215+0,465 \mathrm{PAK}+0,357 \mathrm{PTI}+0,112 \mathrm{KAP}+0,523 \mathrm{KPP}+\mathrm{e}$, dimana pembahasan regresi tersebut adalah: Nilai konstanta $(\alpha)$ sebesar 17,215 artinya jika variabel-variabel independen yaitu Penerapan Akuntabilitas Keuangan, Pemanfaatan Teknologi Informasi, Kompetensi Aparatur Pemerintah dan Ketaatan Peraturan Perundangan bernilai 0 (nol) maka Kinerja Instansi Pemerintah bernilai 17,215. Nilai koefisien regresi variabel Penerapan Akuntanbilitas Keuangan (PAK) bernilai 0,465 yang dapat diartikan bahwa setiap peningkatan Penerapan Akuntanbilitas Keuangan sebesar 1 Satuan maka akan terjadi peningkatan Kinerja Instansi Pemerintah sebesar 0,465 dengan asumsi variabel lainnya konstan. Nilai koefisien regresi variabel Pemanfaatan Teknologi Informasi (PTI) bernilai 0,357 yang dapat diartikan bahwa setiap peningkatan Pemanfaatan Teknologi Informasi sebesar 1 Satuan maka akan terjadi peningkatan Kinerja Instansi Pemerintah sebesar 0,357 dengan asumsi variabel lainnya konstan. Nilai koefisien regresi variabel Kompetensi Aparatur Pemerintah 
(KAP) bernilai 0,112 yang dapat diartikan bahwa setiap peningkatan Kompetensi Aparatur Pemerintah sebesar 1 Satuan maka akan terjadi peningkatan Kinerja Instansi Pemerintah sebesar 0,112 dengan asumsi variabel lainnya konstan. Nilai koefisien regresi variabel Ketaatan Peraturan Perundangan (KPP) bernilai 0,523 yang dapat diartikan bahwa setiap peningkatan Ketaatan Peraturan Perundangan sebesar 1 Satuan maka akan terjadi peningkatan Kinerja Instansi Pemerintah sebesar 0,523 dengan asumsi variabel lainnya konstan.

\section{Uji t (Parsial)}

Berdasarkan hasil analisis pada tabel 6, maka diperoleh hasil uji t yang diperlukan untuk menguji signifikansi konstanta dan variabel indepeden. Untuk variabel Penerapan Akuntabilitas Keuangan (X1) nilai signifikannya adalah $0,000<0,05$, sehingga Hipotesis $1(\mathrm{H} 1)$ dari penelitian ini diterima. Hal ini menunjukan bahwa Penerapan Akuntabilitas Keuangan (X1) berpengaruh terhadap Kinerja Instansi Pemerintah.

Berdasarkan hasil analisis pada tabel 6, maka diperoleh hasil uji t yang diperlukan untuk menguji signifikansi konstanta dan variabel indepeden. Untuk variabel Pemanfaatan Teknologi Informasi (X2) nilai signifikannya adalah $0,000<0,05$, sehingga Hipotesis 2 (H1) dari penelitian ini diterima. Hal ini menunjukan bahwa Pemanfaatan Teknologi Informasi (X2) berpengaruh terhadap Kinerja Instansi Pemerintah.

Berdasarkan hasil analisis pada tabel 6, maka diperoleh hasil uji t yang diperlukan untuk menguji signifikansi konstanta dan variabel indepeden. Untuk variabel Kompetensi Aparatur Pemerintah (X3) nilai signifikannya adalah $0,008<0,05$, sehingga Hipotesis $3(\mathrm{H} 1)$ dari penelitian ini diterima. Hal ini menunjukan bahwa Kompetensi Aparatur Pemerintah (X3) berpengaruh terhadap Kinerja Instansi Pemerintah.

Berdasarkan hasil analisis pada tabel 6, maka diperoleh hasil uji t yang diperlukan untuk menguji signifikansi konstanta dan variabel indepeden. Untuk variabel Ketaatan Peraturan Perundangan (X4) nilai signifikannya adalah $0,000<0,05$, sehingga Hipotesis $4(\mathrm{H} 1)$ dari penelitian ini diterima. Hal ini menunjukan bahwa Ketaatan Peraturan Perundangan (X4) berpengaruh terhadap Kinerja Instansi Pemerintah.

\section{Uji F (Simultan)}

Tabel 7 ANOVA ${ }^{a}$

\begin{tabular}{rlc|c|c|c|c}
\hline \multicolumn{1}{l}{ Model } & $\begin{array}{c}\text { Sum of } \\
\text { Squares }\end{array}$ & $\boldsymbol{d f}$ & $\begin{array}{c}\text { Mean } \\
\text { Square }\end{array}$ & $\boldsymbol{F}$ & Sig. \\
\hline $1 \quad$ Regression & 2389,626 & 4 & 597,407 & 74,627 &, $000^{\mathrm{b}}$ \\
\cline { 2 - 7 } & Residual & 1000,651 & 125 & 8,005 & & \\
\hline & Total & 3390,277 & 129 & & & \\
\hline $\begin{array}{l}\text { a. Dependent Variable: KIP } \\
\text { b. Predictors: (Constant), KPP, PAK, KAP, PTI } \\
\text { Sumber: Output SPSS }\end{array}$
\end{tabular}

Dari tabel 7 di atas, diperoleh nilai $F_{\text {hitung }}$ sebesar 74,627. Langkah selanjutnya mencari nilai $F_{\text {tabel }}$ dan membandingkan dengan nilai $F_{\text {hitung. Rumus }}$ 
mencari $\mathrm{F}$ tabel adalah $(\mathrm{k} ; \mathrm{n}-\mathrm{k}), \mathrm{k}=4$ dan $\mathrm{n}=130$. Maka menghasilkan angka $(4 ; 130-4)=(4 ; 126)$, angka ini kemudian kita jadikan acuan untuk mengetahui nilai $F_{\text {tabel }}$ pada distribusi nilai $F_{\text {tabel }}$. Maka didapat nilai $F$ tabel sebesar 2,44. Karena nilai $F_{\text {hitung }} 74,627$ lebih besar dari nilai $F_{\text {tabel }}$ 2,44 maka dapat dikatakan bahwa variabel bebas secara simultan berpengaruh terhadap variabel terikat. Kemudian nilai signifikansi sebesar 0,000. Karena nilai signifikansi lebih kecil dari 0,05 sehingga hipotesis diterima, artinya Penerapan Akuntabilitas Keuangan, Pemanfaatan Teknologi Informasi, Kompetensi Aparatur Pemerintah dan Ketaatan Peraturan Perundangan secara simultan berpengaruh terhadap Kinerja Instansi Pemerintah.

\section{Koefisien Determinasi (R2)}

Tabel 8 Model Summary ${ }^{b}$

\begin{tabular}{|c|c|c|c|c|c|}
\hline Model & $\boldsymbol{R}$ & R Square & $\begin{array}{c}\text { Adjusted } R \\
\text { Square }\end{array}$ & $\begin{array}{l}\text { Std. Error of } \\
\text { the Estimate }\end{array}$ & $\begin{array}{l}\text { Durbin- } \\
\text { Watson }\end{array}$ \\
\hline 1 &, $840^{\mathrm{a}}$ & ,705 &, 695 & 2,829 & 1,986 \\
\hline
\end{tabular}

Koefisien determinasi ( $R$ Square) sebesar 0,705 atau 70,5\% artinya bahwa Penerapan Akuntabilitas Keuangan, Pemanfaatan Teknologi Informasi, Kompetensi Aparatur Pemerintah dan Ketaatan Peraturan Perundangan mempengaruhi Kinerja Instansi Pemerintah sebesar 70,5\%. Sedangkan sisanya sebesar 29,5\% dijelaskan oleh variabel lain atau faktor lain yang tidak dimasukan dalam penelitian ini.

\section{KESIMPULAN}

Secara parsial penerapan akuntabilitas keuangan berpengaruh terhadap kinerja instansi pemerintah (good governance). Secara parsial pemanfaatan teknologi informasi berpengaruh terhadap kinerja instansi pemerintah (good governance). Secara parsial kompetensi aparatur pemerintah berpengaruh terhadap kinerja instansi pemerintah (good governance). Secara parsial ketaatan peraturan perundangan berpengaruh terhadap kinerja instansi pemerintah (good governance). Secara simultan penerapan akuntabilitas keuangan, pemanfaatan teknologi informasi, kompetensi aparatur pemerintah dan ketaatan peraturan perundangan berpengaruh terhadap kinerja instansi pemerintah (good governance) dengan besar pengaruh $70,5 \%$.

\section{DAFTAR PUSTAKA}

Ainsworth, Murray, Neville Smith. and Anne Millership. 2007. Managing Performance Managing People. Jakarta: PT. Bhuana Ilmu Populer. Aminah, Siti. 2014. Kuasa Negara Pada Ranah Politik Lokal. Jakarta: Kencana. Andi. 2003. Promosi Efektif dengan Web. Yogyakarta: Wahana Komputer. 
Andrianto, Nico. 2007. Transparasi dan Akuntabilitas Publik Melalui eGovernment. Malang: Bayumedia Publishing.

AntaraNews. 2016. Bupati Bengkalis Desak SKPD Selesaikan Laporan keuangan 2016. Diakses dari: https://riau.antaranews.com/berita/83901/bupatibengkalis-desak-skpd-selesaikan-laporan-keuangan-2016.

Ardianto, 2010. "Pengaruh Penerapan Akuntabilitas Keuangan, Pemanfaatan Teknologi Informasi, Kompetensi Aparatur Pemerintah Daerah, dan Ketaatan Terhadap Peraturan Perundangan Terhadap Akuntabilitas Kinerja Instansi Pemerintah di Kabupaten Kuantan". Skripsi Universitas Islam Riau.

Ardianto, Elvinaro. 2010a. Metode Penelitian Untuk Public Relatios Kuantitatif Dan Kualitatif. Bandung: Simbiosa Rekatama Media.

Arthur, John, Wiliam dan David. 2011. Manajemen Keuangan. Jakarta: Indeks.

Asra, Sumiati. 2013. Metode Pembelajaran. Bandung: Wacana Prima.

Bupati Bengkalis. 2016. Peraturan Daerah Kabupaten Bengkalis Nomor 03 Tahun 2016 Tentang Pembentukan dan Susunan Perangkat Daerah Kabupaten Bengkalis.

Diharna. 2004. Kinerja Pemerintah Daerah (Isu dan Teori Pembangunan) Volume I Nomor 03. Bandung: Program Pascasarjana STPDN Depdagri Republik Indonesia.

Dwiyanto. 2003. Reformasi Tata Pemerintahan don Otonomi Daerah. Yogyakarta: Pusat Studi Kependudukan dan Kebijakan UGM.

Ebta, Setiawan. 2015. Kamus Besar Bahasa Indonesia (KBBI) edisi III, Kamus online versi 1.4. Diakses dari: http://kbbi.web.id.

Eryana. 2016. "Pengaruh Kompetensi Profesional Dan Lingkungan Kerja Terhadap Kinerja Dosen". IQTISHADUNA: Jurnal Ilmiah Ekonomi Kita 5 (2), 206-226.

Halim, Abdul. 2008. Akuntansi Sektor Publik: Akuntansi Keuangan Daerah, Edisi Empat. Jakarta: Penerbit Salemba Empat.

Hamzah dan Nina Lamatenggo. 2011. Teknologi Komunikasi dan Informasi Pembelajaran. Jakarta: Bumi Aksara.

Hartini, Sri, Setiajeng dan Tedi. 2014. Hukum Kepegawaian di Indonesia. Jakarta: Sinar Grafika.

Hutapea, Parulian dan Nurianna Thoha. 2008. Kompetensi Plus. Jakarta: PT Gramedia Pustaka Utama.

Iskandar. 2009. Metodologi Penelitian Pendidikan dan Sosial. Jakarta: GP Press.

Jogiyanto. 2005. Analisis dan Desain Sistem Informasi. Yogyakarta: Penerbit Andi.

Kansil dan Christine. 2008. Sistem Pemerintahan Indonesia. Jakarta: Bumi Aksara.

Kamang. 2009. Peran Teknologi Informasi Di Bidang Pemerintahan. Jatinagor.

Kementerian Keuangan Republik Indonesia. 2001. Keputusan Menteri Keuangan Nomor 355/KMK.07/2001 tentang Sistem Akuntansi Keuangan Daerah.

Mahmudi. 2010. Manajemen Keuangan Daerah. Jakarta: Penerbit Erlangga.

Mardiasmo. 2009. Akuntansi Sektor Publik. Yogyakarta: Andi.

Mardoto. 2009. Good Governance dan Clean Good Governance. Jakarta: Taruma Negara University Press. 
Mardoto. 2009a. Mengkritisi Clean And Good Governance Di Indonesia. Diakses dari: http://mardoto.com.

Mishra, Satish Chandra. 2000. "Pemerintah dan Pemerintahan: Memahami Ekonomi Politik Reformasi Institusi”. Jurnal Reformasi Ekonomi 1 (2).

Moeheriono. 2009. Pengkuran Kinerja Berbasis Kompetensi. Bogor: Ghalia Indonesia.

Muins. 2000. Kompetensi Profesi dan Individu. Jakarta: Erlangga.

Nico. 2007. Transparasi dan Akuntabilitas Publik Melalui e-Government. Malang: Bayumedia Publishing.

Palan. 2007. Competency Management: Teknis Mengimplementasikan Manajemen Sumber Daya Manusia Berbasis Kompetensi Untuk Meningkatkan Daya Saing Organisasi. Jakarta: Salemba Empat.

Prasetijo. 2009. Good Governance Dan Pembangunan Berkelanjutan. Diakses dari: http://prasetijo.wordpress.com.

Prasetijo. 2009a. Prinsip-Prinsip Dasar Good Corporate Governance. Jakarta: Total Media.

Prayitno, Widodo dan Suprapto, 2002. Standarisasi Kompetensi Pegawai Negeri Sipil Menuju Era Globalisasi Global. Seri Kertas Kerja Volume II Nomor 05. Jakarta: Pusat Penelitian dan Pengembangan BKN.

Rasul, Syahrudin. 2003. Pengintegrasian Sistem Akuntabilitas Kinerja dan Anggaran dalam Perspektif UU NO. 17/2003 Tentang Keuangan Negara. Jakarta: PNRI.

Rasyad, Kasdihan. 2003. Metode Statistik Deskriptif. Jakarta: Grasindo.

Republik Indonesia. 2003. Undang-undang Nomor 13 Tahun 2003 pasal 1 ayat 10 tentang Ketenagakerjaan.

Republik Indonesia. 2004. Undang-undang Nomor 23 Tahun 2004, dimana yang telah digantikan dengan Undang-Undang No. 9 Tahun 2015.

Republik Indonesia. 2005. Peraturan Pemerintah No. 24 Tahun 2005 Tentang Standar Akuntansi Pemerintah.

Republik Indonesia. 2014. Peraturan Presiden Republik Indonesia No. 29 Tahun 2014 tentang Sistem Akuntabilitas Kinerja Instansi Pemerintah pengganti dari Instruksi Presiden No.7 Tahun 1999 tanggal 15 Juni 1999.

Republik Indonesia. 2014a. Undang-undang Nomor 5 Tahun 2014 Tentang Kompetensi.

Said, Sudirman dan Nizar Suhendra. 2002. Korupsi dan Budaya Masyarakat Indonesia Jakarta: Aksara Foundation.

Sedamayanti. 2003. Good Governance (Kepemimpinan yang Baik) dalam Rangka Otonomi Daerah. Bandung: Penerbit Mandar Maju.

Sekaran. 2006. Metodologi Penelitian Untuk Bisnis, Edisi 4 Buku 1. Jakarta: Salemba Empat.

Sipka. 2017. Lembaga Administrasi Negara Modul I.

Sulistyaningrum. 2005. Akuntansi Sektor Publik. Jakarta: Salemba Empat.

Sumarni, Sri. 2012. Metodologi Penelitian Pendidikan. Yogyakarta: Insan Madani.

Sumiati. 2010. Metode Pembelajaran. Bandung: Wacana Prima.

Thoha, Miftah. 2010. Manajemen Kepegawaian Sipil Di Indonesia. Jakarta: Kencana. 
Ulum, Ihyaul. 2004. Akuntansi Sektor Publik: Sebuah Pengantar. Malang: Universitas Muhammadyah Malang.

Umar, Husein. 2005. Metode Penelitian Untuk Skripsi Dan Tesis Bisnis. Jakarta: PT. Raja Grafindo Persada, Edisi Baru.

Walter, Charles, Thomas dan Themin. 2011. Akuntansi Keuangan. Jakarta: Penerbit Erlangga.

Wasistiono, Sadu. 2004. Kinerja Pemerintah Daerah (Pengembangan Organisasi Fungsional di Lingkungan Pemerintah Daerah) Volume I Nomor 03. Bandung: Program Pascasarjana STPDN DEPDAGRI Republik Indonesia.

Wibowo. 2008. Sistem Manajemen Kinerja. Jakarta: Rajawali Pers. 